\title{
Real Time PCR and Importance of Housekeepings Genes for Normalization and Quantification of mRNA Expression in Different Tissues
}

\author{
Emanuela de Lima Rebouças ${ }^{1}$, José Jackson do Nascimento Costa ${ }^{1}$, Maria Juliane Passos ${ }^{1}$, \\ José Renato de Sousa Passos ${ }^{1}$, Robert van den Hurk ${ }^{2}$ and José Roberto Viana Silva ${ }^{1 *}$ \\ ${ }^{1}$ Nucleo de Biotecnologia de Sobral; Universidade Federal do Ceara; 62042-280; Sobral - CE - Brasil. \\ ${ }^{2}$ Department of Pathobiology; Faculty of Veterinary Medicine; Utrecht University; Utrecht - The Netherlands
}

\begin{abstract}
The aim of this review was to evaluate the importance of the real-time PCR ( $R$ RT-PCR) as a technique for mRNA expression analysis in different tissues. Real-time PCR is widely used for quantification of mRNA levels and is a fundamental tool for basic research, molecular medicine and biotechnology. Genes of references are expressed in a wide variety of tissues and cells with minimal variations in their expression levels, and thus are used to normalize data of mRNA quantification. Software programs, such as geNorm, BestKeeper and NormFinder, have been developed to perform the normalization of data, which help to choose the most stable reference gene. Several genes, such as GAPDH, $\beta$-actin, $\beta$-tubulin, PGK, UBQ, RPL-19 and $18 S$ rRNA have been suggested as standards in PCR studies, but these genes can have variation in their expression in different tissues, reinforcing the idea that there is no ideal reference gene.
\end{abstract}

Key words: PCR, normalization, reference genes, gene expression, mRNA

\section{INTRODUCTION}

The polymerase chain reaction (PCR) is a sensitive technique by which a single DNA molecule can serve as a template for amplification (Azevedo et al. 2003). A variant of this method is real-time quantitative PCR (qRT-PCR), which allows quantification of a specific region of DNA. This technique has been successfully used to evaluate the levels of mRNA in a given cell type. Reference or housekeeping genes are expressed constitutively by different cell types (Nelson and Cox 2004) and are used to normalize the data (Karge et al. 1998). The best known housekeeping genes in literature are glyceraldehyde-3-phosphate desidrogenase (GAPDH), $\beta$-actin, ribosomal proteins (RPL), ubiquitin (UBQ), $\beta$-tubulin, $18 \mathrm{~S}$ ribosomal protein (18S rRNA) and phosphoglycerate kinase (PGK). Although the products of these genes are constitutively expressed, the variation in the levels of their messenger RNA in certain experimental conditions shows genetic instability, which makes these genes inappropriate in certain situations. Dheda et al. (2004) have shown that some reference genes are highly specific for a particular model and that experimental validation for each situation is a crucial requirement. Specific programs have been developed to choose the most suitable reference genes for each experimental model. GeNorm uses the geometric mean of more than one reference gene, because multiple reference genes reduce the variations and errors in

*Author for correspondence: roberto_viana@yahoo.com 
the analysis of the final expression (Vandesompele et al. 2002). The BestKeeper makes the best correlation of the average variation for all pairs of candidate reference and calculates the geometric mean of the pair more suitable (Pfaffl et al. 2004), while NormFinder uses a model-based approach to order variations among subgroups and prevents the selection of co-regulated genes (Andersen et al. 2004). This review aims to discuss (1) the efficiency of PCR in real time, (2) the reference genes more frequently used, and (3) the programs developed for data normalization between the samples.

\section{POLYMERASE CHAIN REACTION (PCR) AND REAL-TIME PCR}

The PCR reaction consists of different stages, which includes DNA denaturation for the separation of double stranded, primers association by hydrogen bonds to the DNA target in a single chain and extension of the primers by synthesizing the complementary strand, catalyzed by DNA polymerase (Mullis and Faloona 1987). The efficiency and specificity of PCR is dependent on various parameters such as the length of the amplicons and the specificity of hybridization and melting temperature of the primers. The primer design is, therefore, of fundamental importance for the success of experiments with PCR, but can be time consuming and repetitive (Gervais et al. 2010). Bustin (2002) stated that replicates with 25 to 40 cycles could be made which would increase the initial concentration of DNA.

In the last decade, a variant of conventional PCR, the real-time quantitative PCR (qRT-PCR), has been important in molecular diagnostics because of its high sensitivity (Abbott et al. 1988; Syvänen et al. 1988). The application of real-time PCR has been showing increasingly usable in different areas of functional genomics, as well as in molecular medicine, virology, microbiology and biotechnology (Bustin 2005). This technique is used to amplify and simultaneously quantify a specific region of the DNA molecule. In the conventional PCR, electrophoresis is used to assess the product of amplification, while in qRTPCR, fluorescent molecules are used for the chemical reaction, which allows the quantification of the amplicon.

The SYBRGreen provided the simplest method for the detection and quantification of the PCR products in real-time reactions with high sensitivity (Nygard et al. 2007). The SYBR Green binds to the double-stranded DNA and emits light upon excitation. As the reaction proceeds and the PCR products accumulate, the fluorescence increases proportional to the amount of specific DNA present in the original sample (Pabla and Pabla 2008). As the amplification starts, more SYBRGreen molecules are associated with the newly synthesized double-stranded DNA and the fluorescence is steadily increased at a specific wavelength that is measured after each amplification cycle. The step at which the fluorescence exceeds the background at the exponential phase of the amplification, the cycle threshold $(\mathrm{Ct})$ or crossing point $(\mathrm{CP})$, is therefore recorded (Wong and Medrano 2005). The SYBR Green is added in the PCR reaction along with other reactants and a laser detector is used to detect the level of fluorescence. The presence of double stranded DNA in the solution is capable of increasing the light emission at about 100 times to the same concentration of SYBR Green. This fluorophore is a nonspecific agent and reveals any double strand generated in the PCR (Pabla and Pabla 2008). To quantify the levels of mRNA for the growth factor in the mammalian ovaries, the group has used the SYBR Green (Frota et al. 2010; Costa et al. 2012). The main advantages of using this fluorophore are the relative simplicity and the reduced costs when compared to other methods.

The TaqMan is another system of light emission that increases the specificity of the reaction, but it has a higher cost, especially because the use of a modified oligonucleotide primers in addition to the usual PCR. These probes are specific for a gene segment and present a fluorophore at position $5^{\prime}$ capable of absorbing the light energy emitted by the equipment and dissipate it as light and heat in the wavelength higher than the original. However, in its native position, all light emitted by the fluorophore is absorbed by the chelating substance present in the 3' end of the probe. Thus, the optical system of the equipment is not capable of detecting the fluorescence in the reaction tube. On the other hand, if the reaction is able to generate the amplicons, the probe will hybridize with the target and will be exposed to exonuclease activity of polymerase. As a result, the probe will be degraded and the fluorophore, away from the chelating substance, no longer would be able to absorb the light emitted (Bustin 2002). The equipment for real-time PCR uses a light source 
capable of exciting the fluorophore involved in the reaction. The TaqMan technique has several advantages over the classical quantitative PCR system. The use of fluorescent dye-labelled probes increases the sensitivity of the system by at least seven orders of magnitude and gives rise to a linear relationship between the copy number and $\mathrm{Ct}$ values (Leutenegger et al. 1999). The fluorescence produced by the sample is detected by the system. In this new situation, each light stimulus generated by the equipment matches with the second light emission by the fluorophore. Therefore, the light emission is proportional to the amount of product generated in the reaction tube. This, in turn, is proportional to the amount of initial targets for the amplification reaction (Bustin et al. 2005).

Molecular beacons (MBs) are single-stranded nucleic acid molecules that possess a hairpin structure (Wang et al. 2009) and the loop portion of the hairpin structure is the probe sequence complementary to the target. A fluorophore, often called reporter, is linked to one end of the strand and a quencher is linked to the other end. Probe hybridization is highly specific by nature because molecular beacons are designed to thermodynamically favor the quenching hairpin structure rather than to hybridize to nonexact matches (Marras et al. 1999). The MBs have become a class of DNA probes that is widely used in chemistry, biology, biotechnology and medical sciences for biomolecular recognition (Tan et al. 2004; Weile and Knabbe 2009; Sidoti et al. 2012).

The LightCycler tecnology $\left(\right.$ Roche $^{\circledR}$ ) combines continuous fluorescence monitoring of the PCR and rapid-cycle PCR within glass capillaries (Wittwer et al. 1997a, b); it uses the fluorogenic hydrolysis or fluorogenic hybridization probes for the quantification (Ririe et al. 1997) in real-time fluorescence PCR providing a greater speed than the conventional PCR. The LightCycler technology uses two fluorescent oligonucleotide probes (one labeled at the $3^{\prime}$ and the other at the $5^{\prime}$ end) with a phosphorylation modification at the $3^{\prime}$ end to prevent the extension. This approach has been introduced as a practical alternative to the conventional PCR for the identification of microorganisms (Woo et al. 1998), determination of genotype (Nauck et al. 1999) and detection of mutation (Mangasser-Stephan et al. 1999).

The LUX real-time PCR (Light Upon eXtension real-time PCR) employs a single-labelled primer with a fluorophore at the $3^{\prime}$ - end and a corresponding unlabelled primer. The labelled primer is designed as an oligonucleotide forming a hairpin structure within a $5^{\prime}$-short tail sequence of 4-6 nucleotides which is complementary to the $3^{\prime}-$ end of primer where the fluorophore is located (Nazarenko 2006). The LUX assay does not require oligonucleotide probe and quencher molecule, instead, it uses only two primers - like conventional PCR - one of which is labelled with a fluorophore molecule. This set-up enables melting curve analysis on completion of the amplification, which provides a convenient and reliable way for confirming its specificity (Kiss et al. 2006). This technique simplifies the PCR kinetics and the hairpin oligonucleotides prevent primer-dimer formation and mispriming (Nazarenko et al. 2002).

The real time PCR technique is effective to measure the absolute transcript and provides valuable quantitative information on gene expression from different sources and samples (Peters et al. 2004; Huggett et al. 2005; Nolan et al. 2006). It is a flexible and sensitive quantitative method (Wang and Brown 1999; Bustin et al. 2000). The quantification of gene expression has many advantages over other techniques such as shortest time, low cost of reagents and rapid results. Compared to the classical PCR, one of the main advantages of real-time PCR is its speed to provide reliable data. Typically, the time of realtime PCR varies from 20 minutes to $2 \mathrm{~h}$. Indeed, the time required to change temperature is a limiting factor responsible for the duration of an experiment in the classical PCR. Moreover, the amplification by the real time PCR can be performed on the machines that can accommodate up to 384 wells and several rounds of amplification to be carried out for $24 \mathrm{~h}$ interrupted (Schnerr et al. 2001; Wurmbach et al. 2003).

The quantification in real time the exponential phase is not affected by any component of the reaction. Despite small differences in the levels of transcription measured by the conventional PCR, a series of optimizations and post-PCR manipulations are required. These optimizations should be performed for each individual sample, because the expression of RNA can vary widely between different samples. Thus, real time PCR has been recognized as the method of choice due to sensitivity and accuracy in the quantification of mRNA transcripts (Bustin 2002).

Real-time PCR has been successfully used to compare the levels of mRNA in blood 
mononuclear cells between the healthy individuals and those affected by the tuberculosis (Dheda et al. 2004). This technique is very efficient to measure the levels of mRNA of multiple genes in the samples of ovarian follicles at different stages of development (Celestino et al. 2010; Frota et al. 2010), of oocytes and pre-implanted embryos (Robert et al. 2002). Real-time PCR has also shown a good performance during the quantification of RNA in the embryos of domestic animals (Fink et al. 1998).

The applicability of this technique in reproduction can be found in the oocytes and cumulus cells undergoing maturation in vitro in the horse (Begnini 2010) during the final follicular development (Kawashima et al. 2008; Chen et al. 2009) and in the embryos before (Bebbere et al. 2008; Nemcova et al. 2006) and after their cryopreservation (Leoni et al. 2009). In addition, Pabla and Pabla (2008) showed that PCR is the main reason for the advent of recombinant DNA technology and great achievements as mammalian cloning and human genome project would not have been possible without their existence.

\section{STRATEGIES FOR NORMALIZATION OF mRNA EXPRESSION}

The levels of mRNA are generally normalized to avoid the deviations from the processes of measurement, such as variation of the executions, the disparities in terms of quantity and quality of mRNA between the samples caused by pipetting errors, and differences in the efficiency of enzymes used for reverse transcription and amplification steps (Banda et al. 2007). Despite being widely used for the quantification of mRNA in the biological samples, the real time PCR has some problems associated with its use, which includes variability of RNA extraction protocols that may inhibit the PCR efficiency (Bustin et al. 2004). It is important to choose a method of regulation to control the errors. Several strategies have been proposed for data normalization in realtime PCR. According to Huggett et al. (2005), some strategies can be used for normalization in real-time PCR. Normalization using tissue samples with similar sizes and volumes may be relatively easy, but may not be biologically representative, as these samples may have different conditions that can lead to an experimental error. The genes of references or housekeeping appear as the normalizing real-time PCR. The reference genes or housekeeping genes are expressed in a wide variety of tissues and cell types and show no or only minimal changes in expression levels between the individual samples and experimental conditions. These genes are used to normalize the mRNA levels of genes of interest before the comparison between different samples by the real time PCR. The right choice is crucial to properly analyze the results of qRT-PCR (Suzuki et al. 2000; Radonic et al. 2004). These reference genes are responsible for measuring and reducing the errors from variations among the samples, extraction and RNA quality and efficiency in cDNA synthesis, internal controls and the different experimental samples (Tichopad et al. 2003, 2004; Peters et al. 2004), like in normal cells or diseased tissue (Huggett et al. 2005).

A housekeeping gene ideally should be stable, expressed in the cells and tissues of interest that do not show changes under the experimental conditions or disease state. However, there is no ideal housekeeping gene (Vandesompele et al. 2002). Typically, the used housekeeping genes show variability in expression levels in different tissues (Selvey et al. 2001; Ohl et al. 2005), emphasizing the importance of evaluation studies to identify the most stable housekeeping gene in different tissues and/or disease states before the start of any study with real time PCR. Vandesompele et al. (2002) proposed to use the geometric mean of all the genes for normalization, and, depending on the tissue, recommended the use of three to five different control genes.

Hundreds of genes of references have been identified by the microarray analysis and many of these can be used as control (Warrington et al., 2000). For the normalization of mRNA expression, the most commonly references genes used in the real-time PCR are glyceraldehyde-3phosphate dehydrogenase (GAPDH), $\beta$-actin, $\beta$ tubulin, phosphoglycerate kinase (PGK), ubiquitin (UBQ), ribosomal protein 19 (RPL-19) and 18S ribosomal RNA (18S rRNA).

\section{GLYCERALDEHYDE - 3 - PHOSPHATE DEHYDROGENASE (GAPDH)}

A widely used as a housekeeping gene is the glyceraldehyde-3-phosphate dehydrogenase (GAPDH) is an enzyme that catalyzes the sixth step of glycolysis, a process in which glucose is 
converted into pyruvate. Its role in glycolysis is not its only function, since it still participates in DNA repair (Meyer-Siegler et al. 1991) and transcriptional regulation (Sirover 2005). As one of the most common reference genes, GAPDH is often used to normalize the gene expression data, being used as an endogenous control in the quantitative analysis of RT-PCR, since in some experimental systems, its expression is very constant (Edwards and Denhardt 1985; Winer et al. 1999). However, the concentrations of GAPDH may vary between different individuals (Bustin and Mckay 1999), for example, during the pregnancy (Cale et al. 1997), with the development stage (Puissant et al. 1994; Calvo et al. 1997) and during the cell cycle (Mansur et al. 1993).

According to Robert et al. (2005), studies with qRT-PCR determined the expression of 1,718 genes using GAPDH as reference gene in 72 kinds of normal human tissues. The use of GAPDH in the studies with clinical samples of cervical human tissues HPV-positive appeared as a reliable strategy for the normalization in qRT-PCR using the program NormFinder (Shen et al. 2010). On the other hand, GAPDH was not suitable as an internal control in rabbit tissues (Deindl et al. 2002) and in nucleated human blood cells (Bustin et al. 1999).

In bovine oocytes, GAPDH was selected as reference gene because its expression showed stability (Van Tol et al. 2007); in zebrafish embryos, the GAPDH gene was considered less stable (Lin et al. 2009). In fibroblast cell lineages of mice under different treatment conditions with antidepressants, the levels of GAPDH were unstable (Sugden et al. 2010).

\section{B-ACTIN}

The $\beta$-actin gene encodes a structural protein of cytoskeleton, and is perhaps the most widely used gene for normalization in the experiments of gene expression (Pohjanvirta et al. 2006). $\quad \beta$-actin showed high stability in fresh and in vitro cultured goat preantral follicles, (Frota et al. 2010). In asthmatic children, $\beta$-actin can be used as housekeeping gene in the studies of gene expression in human respiratory epithelial cells (He et al. 2008). On the other hand, Dheda et al. (2004) found that in the patients with tuberculosis, $\beta$-actin showed maximum variations in its expression in the blood cells, being inappropriate for standardization. For the samples of human skeletal muscles exposed to creatine supplementation on short-term and high intensity exercise, the $\beta$-actin gene was considered a valid option for real-time PCR analysis (Murphy et al. 2003). In the studies with lymphoid cells in cattle (BL-3), $\beta$-actin was stable when analyzed by the program NormFinder (Anstaett et al. 2010).

In the patients undergoing renal transplantation, acute rejection and antirejection therapy, the gene $\beta$-actin is influenced in its expression, which makes it unsuitable for standardization (Gibbs et al. 2003). During the analysis of the expression of interstitial cells in the heart valves in sheep, the gene $\beta$-actin was considered invalid (Yperman et al. 2004). According to Fu et al. (2010) in normal ovarian tissue, or in ovaries with endometriomas or various types of tumors, $\beta$-actin showed low stability among the groups. Several data have shown that the genes of references, such as $\beta$ actin, depending of the tissue, may be inappropriate as internal standard because of its variability (Bustin 2002). Several authors confirmed that the $\beta$-actin used as housekeeping presented differential expression in various tissues (Selvey et al. 2001; Barber et al. 2005).

\section{$\beta$-TUBULIN}

The microtubules are part of the cytoskeleton of eukaryotic cells participating in various cellular processes, such as segregation of chromosomes during mitosis and meiosis, intracellular transport and positioning of organelles. On the walls of the microtubule cylinders, filaments of $\beta$-tubulin are found (Mandelkow and Mandelkow 1993). In the studies with oocytes in germinal vesicle stage, the $\beta$-tubulin gene showed decreased levels of expression after their fertilization when embryos developed until the eight cell stage. This decrease in $\beta$-tubulin expression was followed by a sharp increase at the blastocyst stage, indicating that this housekeeping gene was not an ideal gene to use as an as internal standard (Robert et al. 2002). On the other hand, the $\beta$-tubulin did not appear to be suitable for normalization of mRNA levels in the cultured in goat preantral follicles (Frota et al. 2010). 


\section{UBIQUITINA (UBQ)}

The Ubiquitin (UBQ) is a small protein composed of 76 amino acids, which plays a key role in the processes of protein degradation, DNA repair, signal transduction and transcription regulation by endocytosis (Christensen et al. 1992; Chan et al. 1995; Okazaki et al. 2000). The UBQ is a highly conserved protein of 8 kilodaltons, with 72 of the 76 amino acids present in fungi, plants and animals which bind covalently to lysine residues (Lys) in the target proteins (Callis and Vierstra 1989; Hershko and Ciechanover 1992). The UBQ binds to a protein that acts as a substrate for the attachment of UBQ, which leads to the formation of chains of polyubiquitin. Classically, poliubiquitination is a signal that directs the proteins to the proteasome, where UBQ is recycled and the protein is degraded (Hershko and Ciechanover 1992). Ubiquitination also remodels the surface of proteins, and therefore, potentially affects the properties such as stability and activity (Pickart and Eddins 2004), interactions with other proteins and plays a role in subcellular localization (Mukhopadhyay and Riezman 2007).

Andersen et al. (2004) conducted studies to identify appropriate genes to normalize the quantitative data in real-time PCR in bladder and colon cancer and ubiquitin appeared as a potential housekeeping gene. Van Tol et al. (2007) showed that ubiquitin was one of the most stable genes in fresh or in vitro cultured bovine cumulus cells, as well as in different phases of meiosis in oocytes. Ubiquitin was one of the housekeeping genes that showed greater stability in goat preantral follicles before and after culture in vitro (Frota et al. 2010). Ubiquitin was also a stable reference gene in human liver, leukocytes and bone marrow, but in studies with liver of aging rats, ubiquitin was shown to be the most unstable gene (Chen et al. 2006).

\section{RNA RIBOSOMAL 18 S - RNAr 18 S}

In eukaryotes, the genes most conserved and most widely used are those that encode ribosomal RNA (rRNA) (Eickbush and Eickbush 2007). These genes encode small subunit ribosomal (18S rRNA) and two largest subunits ribosomal (28S and 5.8S RNA) in a transcription unit, constituting about $85-90 \%$ of total cellular RNA, and are very useful as internal controls (Paule and White 2000). This housekeeping gene has been shown to be optimal in the studies with rat liver cells (Bustin 2000) and normal lymphoblastic cells (Banda et al. 2007). The rRNA was constant during the embryonic development to eight cells, followed by an increase in expression during the blastocyst stage (Robert et al. 2002). In addition, 18S RNA showed a greater instability than other reference genes in goat preantral follicles before and after the culture (Frota et al. 2010), as well as in the healthy and diseased human ovarian tissue (Fu et al. 2010). According to Bustin (2000), there are two other drawbacks to the use of rRNA for normalization: (1) when quantifying targets that have been enriched for mRNA, rRNA is lost during mRNA purification, and (2) rRNA is expressed at much greater levels than the target mRNAs.

\section{PHOSPHOGLYCERATE KINASE - PGK}

The PGK is a glycolytic enzyme that catalyzes the conversion of 1,3 diphosphoglycerate to 3phosphoglycerate and plays a key role in the generation of ATP during the glycolysis. Therefore, PGK is classified in the group of genes of glycolysis together with the GAPDH (CohenSolal et al. 1994; He et al. 2008). Van Tol et al. (2007) showed that, in the cumulus cells around maturing bovine oocytes, PGK was the most stable reference gene among the genes analyzed. Steinau et al. (2006) showed that PGK could be used as housekeeping gene in human cervical cells. High stability of the PGK was detected in the cells of the liver, spleen and hypothalamus of rats (Pohjanvirta et al. 2006). In addition, PGK was designated as the most suitable gene in human keratinocytes exposed to UVB (Balogh et al. 2008). However, in the studies with bronchial epithelial cells in humans, the PGK was not considered ideal for normalization in real-time PCR (He et al. 2008).

\section{RIBOSOMAL PROTEIN - RPL}

Several authors have suggested the ribosomal protein gene as internal control for normalization of data by real time PCR. Van Tol et al. (2007) used RPL-15 to normalize the gene mRNA levels in the samples from cumulus cells in cattle. Shen et al. (2010) demonstrated that the gene RPLP0 could be considered reliable to normalize the gene 
expression, while Steinau et al. (2006) recommend the use of ribosomal protein L4 (RPL4) in the cells of the cervix. The gene RPL-7 was considered very stable in the studies with Japanese killyfish (Oryzias latipes), because its expression remained unchanged in various tissues and developmental stages and still under exposure to endocrine disrupting chemicals (Zhang and $\mathrm{Hu}$ 2007). In fresh and in vitro cultured goat preantral follicles, ribosomal protein 19 (RPL 19) was compared with six other reference genes and showed lower stability when compared with the ubiquitin and $\beta$ actin (Frota et al. 2010). Different tissues of healthy sheep had low stability of RPL, making it impractical to use under those conditions (GarciaCrespo et al. 2006).
Several authors have suggested other reference genes as internal controls for the normalization in real-time PCR (Tang et al. 2007; He et al. 2008; Anstaett et al. 2010; Shen et al. 2010; Sugden et al. 2010), for example, $\beta$-2-microglobulin (B2M), succinate dehydrogenase complex subunit A flavoprotein (Sdha), binding protein TATA box (TBP), hypoxanthine guanine phosphoribosyl transferase I (HPRT), factor elongation 1 alpha 1 eukaryotic translation (EEF1A1) calnexina (Canx), cyclophilin A, ribosomal protein (28S), and transferrin receptor (TFRC). The functions of these genes of reference are shown in Table 1.

Table 1 - Reference genes used as internal controls in normalization.

\begin{tabular}{|c|c|c|}
\hline Symbology & Housekeepings Genes for internal control & Physiological functions \\
\hline (B2m) & $\beta$-2-microglobulin (B2M) & $\begin{array}{l}\beta \text { chain molecule major histocompatibility } \\
\text { complex I }\end{array}$ \\
\hline $\begin{array}{l}\text { (Sdha) } \\
\text { (TBP) }\end{array}$ & $\begin{array}{c}\text { Succinate dehydrogenase complex, subunit A, } \\
\text { flavoprotein (Sdha) } \\
\text { Binding protein TATA box (TBP) }\end{array}$ & $\begin{array}{l}\text { Antioxidant enzyme } \\
\text { Phosphorylation pathway } \\
\text { Transcription factor }\end{array}$ \\
\hline (HPRT) & $\begin{array}{l}\text { Hypoxanthine guanine phosphoribosyl } \\
\text { transferase I (HPRT) }\end{array}$ & Enzyme in the pathway of purine \\
\hline (EEF1A1) & $\begin{array}{c}\text { Elongation factor } 1 \text { alpha } 1 \text { eukaryotic } \\
\text { translation }\end{array}$ & Translation elongation factor \\
\hline (Canx) & Calnexin (Canx) & $\begin{array}{l}\text { Protein of calcium ions, located in the } \\
\text { endoplasmic reticulum }\end{array}$ \\
\hline PPIA & Cyclophilin A & $\begin{array}{l}\text { Cyclosporin binding protein /Inhibitor of serine- } \\
\text { threonine phosphatase }\end{array}$ \\
\hline $28 S$ & Ribosomal protein & Ribosomal Subunit \\
\hline TFRC & Transferrin receptor & Cellular uptake of iron \\
\hline
\end{tabular}

\section{PROGRAMS USED NORMALIZATION}

There are some programs to define the most stable gene, where the stability of the expression is referred to as the smallest variation in the levels of constitutive expression of the analyzed samples (Galiveti et al. 2010). Vandesompele et al. (2002) has developed a gene-stability measure termed geNorm, which is based on the assumption that minimally regulated, stable transcribed genes stay in a constant ratio to each other. The transcription ratio of two proper reference genes should be identical in all the samples, regardless of the experimental condition, cell type or life stages. An increased ratio variation corresponds to a decreased transcription stability of one (or both) of the tested genes. The geNorm software program, a visual basic application for Microsoft Excel (http://medgen.ugent.be/ jvdesomp/genorm/) that calculates the pairwise variation of a control gene with all other control genes as the standard deviation of the logarithmically transformed expression ratios. The gene-stability measure $\mathrm{M}$ is defined as the average pairwise variation of a particular gene with all other control genes. Genes with the lowest $M$ value have the most stable transcription. Such genes can subsequently be used to determine a normalization factor for a certain RNA sample. This normalization factor is basically the geometric mean of the transcription levels of the best reference genes and can be used 
to normalize the raw RT-PCR data of a given gene of interest. In this way, the normalization of the RT-PCR data is based on two or three reference genes, which will substantially reduce any potential error.

In 2004, another Excel-based tool, BestKeeper, was released (Pfaffl et al. 2004). This program assesses the genes by pair-wise correlations based on raw crossing points $(\mathrm{CP})$ or cycle threshold $(\mathrm{Ct})$ values, which are then combined into an index (Pfaffl et al. 2004). The BestKeeper uses a combination of descriptive statistics and regression analysis of the $\mathrm{Ct}$ values to identify the reference genes with stable expression. The $\mathrm{Ct}$ values measured in all the samples are grouped for each gene. The genes with $\mathrm{Ct}$ values with standard deviations $>1$ are considered unstable. Two types of linear regression analysis are also performed and a regression analysis is performed between all the possible combinations of the genes, the average total level of all the genes with standard deviation $<1$ in each sample are summed to create the index BestKeeper. The linear regression is then performed between the index and Bestkeeper of each gene. The most suitable reference genes are those with the highest correlation coefficient (r) compared with the index Bestkeeper and standard deviation < 1 (Urschel and O'brien 2008).

The NormFinder is another program released in 2004 and uses a model-based approach to rank the candidates based reference gene expression variations in inter-and intra-group (Andersen et al. 2004). This approach assigns a value to the stability of each candidate gene, but focuses on the variation that can occur between the sample groups rather than the expression on the data set (Robinson et al. 2007). The NormFinder is an algorithm to find the ideal reference genes of a group of candidate genes. In contrast to the geNorm, the NormFinder takes into account information from the groups of samples, such as no treatment / treatment $-1 /-2$ or ill treatment / healthy and the result is a pair of reference genes more stable. The resulting pair can be compensated in the expression, so that one gene, for example, has to be increased in a group, but the other gene has low expression in the same group (Andersen et al. 2004). The model-based approach Norm Finder is advantageous if the subpopulations present differential gene expression (Steinau et al. 2006).
For the selection of housekeeping genes in ovarian follicles before and after culture the geNorm software program has been used by Frota et al. (2010) and Costa et al. (2012). An advantage to the GeNorm algorithm is that it is minimally affected by the expression intensity of the candidate genes. In addition, since the approach is based on multiple pair-wise comparisons, the need for large sample size is attenuated.

\section{FINAL CONSIDERATIONS}

The real-time PCR (RT-PCR) is a modern and efficient tool in measuring the levels of mRNA expression in different types of the samples; their use together with the housekeeping genes are ideal for decreasing the possible errors in RNA extraction and contamination during the manipulations of the samples, thus increasing the quality of cDNA. The selection of an ideal housekeeping gene for each experimental condition is crucial. The use of electronic normalization programs geNorm, NormFinder and Bestkeeper can contribute to the stability analysis of these genes in different types of samples.

\section{ACKNOWLEDEGEMENTS}

We thank CNPq and FUNCAP for financial support, and all members of the animal reproduction research group of the Biotechnology Nucleus of Sobral.

\section{REFERENCES}

Abbott M, Poiesz BJ, Byrne BC, Kwok S, Sninsky JJ, Ehrlich GD. Enzymatic gene amplification: qualitative and quantitative methods for detecting proviral DNA amplified in vitro. J Infect Dis. 1988; 158: 1158-1169.

Andersen CL, Jensen JL, Orntoft TF. Normalization of real-time quantitative reverse transcription - PCR data: A model-based variance estimation approach to identify genes suited for normalization, applied to bladder and colon cancer data sets. Cancer Res. 2004; 64: 5245-5250.

Anstaett OL, Brownlie J, Collins ME, Thomas CL. Validation of endogenous reference genes for qRTPCR normalization in bovine lymphoid cells (BL-3) infected with Bovine Viral Diarrhoea Virus (BVDV). Vet Immunol Immunopathol. 2010; 137:201-207. 
Azevedo MA, Felipe MSS, Brígido MM, Maranhão AQ, Sousa MT. Técnicas básicas em biologia molecular, vol. 2. Brasília: Universidade de Brasília, 2003.

Balogh A, Paragh GJ, Juhasz A. Reference genes for quantitative real time PCR in UVB irradiated keratinocytes. J Photoch Photobio B. 2008; 93: 133139.

Banda M, Bommineni A, Thomas RA, Luckinbill LS, Tucker JD. Evaluation and validation of housekeeping genes in response to ionizing radiation and chemical exposure for normalizing RNA expression in realtime PCR. Mutat Res/Genet Toxicol Environ Mutagen. 2007; 649: 126-134.

Barber RD, Harmer DW, Coleman RA, Clark BJ. GAPDH as a housekeeping gene: analysis of GAPDH mRNA expression in a panel of 72 human tissues. Physiol Genomics. 2005; 21: 389-395.

Bebbere D, Bogliolo L, Ariu F, Fois S, Leoni GG, Tore $\mathrm{S}$, et al. Expression pattern of zygote arrest 1 (ZAR1), maternal antigen that embryo requires (MATER), growth differentiation factor 9 (GDF9) and bone morphogenetic protein 15 (BMP15) genes in ovine oocytes and in vitro-70 produced preimplantation embryos. Reprod Fertil Dev. 2008; 20: 908-915.

Begnini KR. Expressão do gene Bcl-2 relacionado a apoptose em oócitos equinos e células do cumulus [Monografia], Pelotas, Brasil: Universidade Federal de Pelotas; 2010.

Bustin SA. Absolute quantification of mRNA using real-time reverse transcription polymerase chain reaction assays. J Mol Endocrinol. 2000; 25: 169193.

Bustin SA. Quantification of mRNA using real-time reverse transcription PCR (RT-PCR): trends and problems. J Mol Endocrinol. 2002; 29: 23-39.

Bustin SA. Real-time, fluorescence-based quantitative PCR: a snapshot of current procedures and preferences. Expert Rev Mol Diagn. 2005; 5: 493-498.

Bustin SA, Benes V, Nolan T, Pfaffl MW. Quantitative realtime qRT-PCR: a perspective. J Mol Endocrinol. 2005; 34: 597-601.

Bustin SA, Gyselman VG, Siddiqi S, Dorudi S. Cytokeratin 20 is not a tissue-specific marker for the detection of malignant epithelial cells in the blood of colorectal cancer patients. Int J Surg Invest. 2000; 2: 49-57.

Bustin SA, Gyselman VG, Williams NS, Dorudi S. Detection of cytokeratins 19/20 and guanylyl cyclase $\mathrm{C}$ in peripheral blood of colorectal cancer patients. Brit J Cancer. 1999; 79: 1813-1820.

Bustin SA, Mckay IA. The product of the primary response gene BRF1 inhibits the interaction between 14-3-3 proteins and cRaf-1 in the yeast trihybrid system. DNA Cell Biol. 1999; 18: 653-661.
Bustin SA, Siddiqi S, Ahmed S, Hands R, Dorudi S. Quantification of cytokeratin 20, carcinoembryonic antigen and guanylyl cyclase $\mathrm{C}$ mRNA levels in lymph nodes may not predict treatment failure in colorectal cancer patients. Int J Surg Invest. 2004; 108: 412-417.

Cale JM, Millican DS, Itoh H, Magness RR, Bird IM. Pregnancy induces an increase in the expression of glyceraldehydes - 3 - phosphate dehydrogenase in uterine artery endothelial cells. J Soc Gynecol Invest. 1997; 4: 284-292.

Callis J, Vierstra RD. Ubiquitin and ubiquitin genes in higher plants. Oxford Surv Plant Mol Cell Biol. 1989; 6: $1-30$.

Calvo EL, Boucher C, Coulombe Z, Morisset J. Pancreatic GAPDH gene expression during ontogeny and acute pancreatitis induced by caerulein. Biochem Bioph Res Co. 1997; 235: 636-640.

Celestino JJ, Bruno JB, Lima-Verde I.B, Matos MH, Saraiva MV, Chaves RN, et al. Steady-state level of kit ligand mRNA in goat ovaries and the role of kit ligand in preantral follicle survival and growth in vitro. Mol Reprod Devel. 2010; 77:231-240.

Chan YL, Suzuki K, Wool IG. The carboxyl extensions of two rat ubiquitin fusion proteins are ribosomal proteins S27a and L40. Biochem Bioph Res Co. 1995; 215: 682-690.

Chen AQ, Yu SD, Wang ZG, Xu ZR, Yang ZG. Stagespecific expression of bone morphogenetic protein type I and type II receptor genes: Effects of folliclestimulating hormone on ovine antral follicles. Anim Reprod Sci. 2009; 111: 391-399.

Chen J, Rider DA, Ruan R. Identification of valid housekeeping genes and antioxidant enzyme gene expression change in the aging rat liver. J Gerontol. 2006; 61: 20-27.

Christensen AH, Sharrok RA, Quail PH. Maize polyubiquitin genes: structure, thermal perturbation of expression and transcript splicing, and promoter activity following transfer to protoplasts by electroporation. Plant Mol Biol. 1992; 18: 675-689.

Cohen-Solal M, Valentin C, Plassa F, Guillemin G, Danze F, Jaisson F, et al. Identification of new mutations in two phosphoglycerate kinase (PGK) variants expressing different clinical syndromes: PGK Creteil and PGK Amiens. Blood. 1994; 84: 898-903.

Costa JJN, Passos MJ, Leitão CCF, Vasconcelos GL, Saraiva MVA, Figueiredo JR, et al. Levels of mRNA for bone morphogenetic proteins, their receptors and SMADs in goat ovarian follicles grown in vivo and in vitro. Reprod Fertil Develop. 2012; 24(5): 723-732.

Deindl E, Boengler K, Van Royen N, Schaper W. Differential expression of GAPDH and $\beta$-actin in growing collateral arteries. Mol Cell Biochem. 2002; 236: $139-146$. 
Dheda K, Huggett JF, Bustin SA, Johnson MA, Rook G, Zumla A. Validation of housekeeping genes for normalizing RNA expression in real-time PCR. Biotechniques. 2004; 37: 112-119.

Edwards DR, Denhardt DT. A study of mitochondrial and nuclear transcription with cloned cDNA probes. Changes in the relative abundance of mitochondrial transcripts after stimulation of quiescent mouse fibroblasts. Exp Cell Res. 1985; 157: 127-143.

Eickbush TH, Eickbush DG. Finely orchestrated movements: evolution of the ribosomal RNA genes. Genetics. 2007; 175: 477-485.

Fink L, Seeger W, Ermert L, Hanze J, Stahl U, Grimminger F, et al. Real-Time quantitative RT-PCR after laserassisted cell picking. Nat Med. 1998; 4: 1329-1333.

Frota IMA, Leitão CCF, Costa JJN, Brito IR, Van Den Hurk R, Silva JRV Stability of housekeeping genes and expression of locally produced growth factors and hormone receptors in goat preantral follicles. Zygote. 2010; 19: 71-83.

Fu J, Lihong B, Li Z, Zhouhuan D, Xin G, Haofei L, et al. Identification of genes for normalization of quantitative real-time PCR data in ovarian tissues. Acta Biochim Biophys Sin. 2010; 42: 568-574.

Galiveti CR, Rozhdestvensky TS, Brosius J, Lehrach H, Konthur Z. Application of housekeeping npcRNAs for quantitative expression analysis of human transcriptome by real-time PCR. RNA. 2010; 16: 450461.

Garcia-Crespo D, Juste RA, Hurtado A. Correction: Selection of ovine housekeeping genes for normalization by real-time RT-PCR; analysis of PrP gene expression and genetic susceptibility to scrapie. BioMed Central Vet Res. 2006; 48: 2-26.

Gervais AL, Marques M, Gaudreau L. PCRTiler: automated design of tiled and specific PCR primer pairs. Nucleic Acids Res. 2010; 38: 308-312.

Gibbs PJ, Cameron C, Tan LC, Sadek AS, Howell WM. Housekeeping genes and gene expression analysis in transplant recipients: a note of caution. Transpl Immunol. 2003; 12: 89-97.

He JQ, Sandford AJ, Wang IM, Stepaniants S, Knight DA, Kicic A, et al. Selection of housekeeping genes for real-time PCR in atopic human bronchial epithelial cells. Eur Resp J. 2008; 32: 755-762.

Hershko A, Ciechanover A. The ubiquitin system for protein degradation. Ann Rev Biochem. 1992; 61: 761807.

Huggett J, Dheda K, Bustin S, Zumla A. Real-time RTPCR normalization; Strategies and considerations. Genes \& Immunity. 2005; 6: 279-284.

Karge Iii WH, Schaefer EJ, Ordovas JM. Quantification of mRNA by polymerase chain reaction (PCR) using an internal standard and a nonradioactive detection method. Method Mol Biol. 1998; 110: 43-61.
Kawashima I, Okazaki T, Noma N, Nishibori M, Yamashita Y, Shimada M. Sequential exposure of porcine cumulus cells to FSH and/or LH is critical for appropriate expression of steroidogenic and ovulation-related genes that impact oocyte maturation in vivo and in vitro. Reproduction. 2008; 136: 9-21.

Kiss I, Germán P, Sámi L, Antal M, Farkas T, Kardos, G, et al. Application of Real-Time RT-PCR utilising Lux (Light Upon Extension) Fluorogenic Primer for the rapid detection of Avian Influenza Viruses. Acta Vet Hung. 2006; 54(4): 525-533.

Leoni GG, Succu S, Satta V, Paolo M, Bogliolo L, Bebbere $\mathrm{D}$, et al. In vitro production and cryotolerance of prepubertal and adult goat blastocysts obtained from oocytes collected by laparoscopic oocyte-pick-up (LOPU) after FSH treatment. Reprod Fertil Develop. 2009; 21: 901-908.

Leutenegger CM, Klein D, Hofmann-Lehmann R, Mislin C, Hummel U, Böni J, Rapid feline immunodeficiency virus provirus quantitation by polymerase chain reaction using the TaqMan fluorogenic real-time detection system. J Virol Method. 1999; 78: 105-116.

Lin C, Spikings E, Zhang T, Rawson D. Housekeeping genes for cryopreservation studies on zebrafish embryos and blastomeres. Theriogenology. 2009; 71: 1147-1155.

Mandelkow E, Mandelkow E. Monoclonal Anti-aTubulin Conjugate Clone DM1A FITC Conjugate Purified Mouse Immunoglobulin. In: Kreis T, Vale R, editors. Guidebook to the Cytoskeletal and Motor Proteins, Oxford: Oxford University Press; 1993. p. 127-130.

Mangasser-Stephan K, Tag C, Reiser A, Gressner AM. Rapid genotyping of hemochromatosis gene mutations on the LightCycler with fluorescent hybridization probes. Clin Chem. 1999; 45: 18751878.

Mansur NR, Meyer-Siegler K, Wurzer JC, Sirover MA. Cell cycle regulation of the glyceraldehydes - 3 phosphate dehydrogenase uracil DNA glycosylase gene in normal human cells. Nucleic Acid Res. 1993; 21: 993-998.

Marras SA, Kramer FR, Tyagi S. Multiplex detection of single-nucleotide variations using molecular beacons. Genet Anal. 1999; 14: 151-156.

Meyer-Siegler K, Mauro DJ, Seal G, Wurzer J, Deriel JK, Sirover MA. A human nuclear uracil DNA glycosylase is the $37-\mathrm{kDa}$ subunit of glyceraldehydes - 3 - phosphate dehydrogenase. P Natl Acad Sci USA. 1991; 88: 8460-8464.

Mukhopadhyay D, Riezman H. Proteasomeindependent functions of ubiquitin in endocytosis and signaling. Science. 2007; 315: 201-205.

Mullis KB, Faloona FA. Specific Synthesis of DNA in vitro via a Polymerase-catalyzed Chain Reaction. Method Enzymol. 1987; 155, 335-350. 
Murphy RM, Watt KKO, Cameron-Smith D, Gibbons CJ, Snow RJ. Effects of creatine supplementation on housekeeping genes in human skeletal muscle using real-time RT-PCR. Physiol Genomics. 2003; 12; 163174.

Nauck MS, Gierens H, Nauck MA, Marz W, Wieland H. Rapid genotyping of human platelet antigen 1 (HPA-1) with fluorophorelabelled hybridization probes on the LightCycler. Brit J Haematol. 1999; 105: 803-810.

Nazarenko I. Homogeneous detection of nucleic acids using self-quenched polymerase chain reaction primers labeled with a single fluorophore (LUX primers). Method Mol Biol. 2006; 335: 95-114.

Nazarenko I, Lowe B, Darfler M, Ikonomi P, Schuster D, Rashtchian A. Multiplex quantitative PCR using self-quenched primers labeled with a single fluorophore. Nucleic Acids Res. 30(9)-e37.

Nelson D L, Cox MM. Lehninger - Principles of Biochemistry. 4nd ed. New York: W H Freeman; 2004.

Nemcova L, Machatkova M, Hanzalova K, Horakova J, Kanka J. Gene expression in bovine embryos derived from oocytes with different developmental competence collected at the defined follicular developmental stage. Theriogenology. 2006; 65: 1254-1264.

Nolan T, Hands RE, Bustin SA. Quantification of mRNA using real-time RT-PCR. Nat Protoc. 2006; 1: 1559-1582.

Nygard A-B, Jorgensen CB, Cirera S, Fredholm Merete. Selection of reference genes for gene expression studies in pig tissues using SYBR green qPCR. Mol Biol. 2007; 8: 67-72.

Ohl F, Jung $\mathrm{M}, \mathrm{Xu} \mathrm{C}$. Gene expression studies in prostate cancer tissue: which reference gene should be selected for normalization? J Mol Med. 2005; 83: 1014-1024.

Okazaki K, Okayama H, Niwa O. The polyubiquitin gene is essential for meiosis in fission yeast. Exp Cell Res. 2000; 254:143-152.

Pabla SS, Pabla SS. Real-time polymerase chain reaction. A revolution in diagnostics. Resonance. 2008; 13: 369-377.

Paule MR, White RJ. Transcription by RNA polymerases I and III. Nucleic Acids Res. 2000; 28: 1283-1298.

Peters IR, Helps CR, Hall EJ, Day MJ. Real-time RTPCR: Considerations for efficient and sensitive assay design. J Immunol Methods. 2004; 286: 203-217.

Pfaffl MW, Tichopad A, Prgomet C, Neuvians TP. Determination of stable housekeeping genes, differentially regulated target genes and sample integrity: BestKeeper-Excel-based tool using pairwise correlations. Biotechnol Lett. 2004; 26: 509-515.
Pickart CM, Eddins MJ. Ubiquitin: structures, functions, mechanisms. Acta Biochim Biophys Sin. 2004; 1695: 55-72.

Pohjanvirta R, Niittynen M, Lind'En J, Boutros PC, Moffat ID, Okey AB. Evaluation of various housekeeping genes for their applicability for normalization of mRNA expression in dioxin-treated rats. Chem-Biol Interact. 2006; 160: 134-149.

Puissant C, Bayat-Sarmadi M, Devinoy E, Houdebine LM. Variation of transferrin mRNA concentration in the rabbit mammary gland during the pregnancylactation-weaning cycle and in cultured mammary cells. A comparison with the other major milk protein mRNAs. Eur J Endocrinol. 1994; 130: 522-529.

Radonic A, Thulke S, Mackay IM, Landt O, Siegert W, Nitsche A. Guideline to reference gene selection for quantitative real-time PCR. Biochem Bioph Res Co. 2004; 313: 856-862.

Ririe KM, Rasmussen RP, Wittwer CT. Product differentiation by analysis of DNA melting curves during the polymerase chain reaction. Anal Biochem.1997; 245: 154-160.

Robert C, Mcgraw S, Massicotte L, Pravetoni M, Gandolfi F, Sirard MA. Quantification of housekeeping transcript levels during the development of bovine preimplantation. Biol Reprod. 2002; 67: 1465-1472.

Robert DB, Harmer DW, Coleman RA, Clark BJ. GAPDH as a housekeeping gene: analysis of GAPDH mRNA expression in a panel of 72 human tissues. Physiol Genomics. 2005; 21: 389-395.

Robinson TL, Sutherland IA, Sutherland J. Validation of candidate bovine reference genes for use with realtime PCR. Vet Immunol Immunop. 2007; 115: 160165.

Schnerr H, Niessen L, Vogel RF. Real time detection of the tri5 gene in Fusarium species by Light CyclerTMPCR using SYBR-Green I for continuous fluorescence monitoring. Int J Food Microbiol. 2001; 71: 53-61.

Selvey S, Thompson EW, Matthaei K, Lea RA, Irving MG, Griffiths LR. Beta-actin an unsuitable internal control for RTPCR. Mol Cell Probes. 2001; 15: 307311.

Shen Y, Li Y, Ye F, Wang F, Lu W, Xie X. Identification of suitable reference genes for measurement of gene expression in human cervical tissues. Anal Biochem. 2010; 405: 224-229.

Sidoti F, Bergallo M, Costa C, Cavallo R. Alternative molecular tests for virological diagnosis. Mol Biotechnol.. 2012; DOI 10.1007/s12033-012-9533-8.

Sirover MA. Novas funções das proteínas glicolíticas, gliceraldeído-3-fosfato desidrogenase, em células de mamíferos. J Cell Biochem. 2005; 95: 45-52. 
Steinau M, Rajeevan SM, Unger ER. DNA and RNA references for qRT-PCR assays in exfoliated cervical cells. J Mol Diag. 2006; 8: 113-118.

Sugden K, Pariante CM, Mcguffin P, Aitchison KJ, D'souza UM. Housekeeping gene expression is affected by antidepressant treatment in a mouse fibroblast cell line. J Psychopharmacol. 2010; 24: 1253-1259.

Suzuki T, Higgins PJ, Crawford DR. Control selection for RNA quantitation. Biotechniques. 2000; 29: 332 337.

Syvänen A-C, Bengtström M, Tenhunen J, Söderlund H. Quantification of polymerase chain reaction products by affinity- based hybrid collection. Nucleic Acid Res. 1988; 16: 11327-11338.

Tan W, Wang K, Drake TJ. Molecular beacons. Curr Opin Chem Biol. 2004; 8: 547-553.

Tang R, Dood A, Lai D, Mcnabb WC, Love DR. Validation of zebrafish (Danio rerio) reference genes for quantitative real-time RT-PCR normalization. Acta Biochim Biophys Sin. 2007; 39: 384-390.

Tichopad A, Didier A, Pfaffl MW. Inhibition of realtime RT-PCR quantification due to tissue-specific contaminants. Mol Cell Probes. 2004; 18: 45-50.

Tichopad A, Dilger M, Schwarz G, Pfaffl, M. W. Standardized determination of real-time PCR efficiency from a single reaction set-up. Nucleic Acids Res. 2003; 31(20): e122.

Urschel MR, O'brien KM. High mitochondrial densities in the hearts of Antarctic icefishes are maintained by an increase in mitochondrial size rather than mitochondrial biogenesis. J Exp Biol. 2008; 211: 2638-2646.

Van Tol HTA, Van Eerdenburg FJCM, Colenbrander B, Roelen BAJ. Enhancement of bovine oocyte maturation by leptin is accompanied by an upregulation in mRNA expression of leptin receptor isoforms in cumulus cells. Mol Reprod Develop. 2007; 75: 578-587.

Vandesompele J, De Paepe A, Speleman F. Elimination of primer dimer artifacts and genomic coamplification using a twostep SYBR Green I Real-Time RT-PCR. Anal Biochem. 2002; 303: 95-98.

Wang K, Tang Z, Yang CJ, Kim Y, Fang X, Li W, et al. Molecular engineering of DNA: molecular beacons. Angew Chem Int Edit. 2009; 48: 856-870.
Wang T, Brown MJ. mRNA quantication by real time Taq-Man polymerase chain reaction: validation and comparison with RNAse protection. Anal Biochem. 1999; 269: 198-201.

Warrington JA, Nair A, Mahadevappa M, Tsyganskaya M. Comparison of human adult and fetal expression and identification of 535 housekeeping maintenance genes. Physiol Genomics. 2000; 2: 143-147.

Weile J, Knabbe C. Current applications and future trends of molecular diagnostics in clinical bacteriology. Anal Bioanal Chem. 2009; 394: 731742.

Winer J, Jung CK, Shackel I, Williams PM. Development and validation of real-time quantitative reverse transcriptase-polymerase chain reaction for monitoring gene expression in cardiac myocytes in vitro. Anal Biochem. 1999; 270: 41-49.

Wittwer CT, Herrmann MG, Moss AA, Rasmussen RP. Continuous fluorescence monitoring of rapid cycle DNA amplifications. Biotechniques. 1997a; 22: 130138.

Wittwer CT, Ririe KM, Andrew RV, David DA, Gundry RA, Balis UJ. The LightCycler: a microvolume multisample fluorimeter with rapid temperature control. Biotechniques. 1997b; 22: 176181.

Wong ML, Medrano JF. Real-time PCR for mRNA quantification. BioTechniques. 2005; 39: 75-85.

Woo TH, Patel BK, Smythe LD, Symonds ML, Norris MA, Weyant RS, et al. Identification of Leptospira inadai by continuous monitoring of fluorescence during rapid cycle PCR. Syst Appl Microbiol. 1998; 21: 89-96.

Wurmbach E, Yuen T, Sealfon SC. Focused microarray analysis. Methods. 2003; 31: 306-316.

Yperman J, De Visscher G, Holvoet P, Flameng W. Beta-actin cannot be used as a control for gene expression in ovine interstitial cells derived from heart valves. J Heart Valve Dis. 2004; 13: 848-853.

Zhang $\mathrm{Z}$, $\mathrm{Hu} \mathrm{J}$. Development and validation of endogenous reference genes for expression profiling of medaka (Oryzias latipes) exposed to endocrine disrupting chemicals by quantitative real-time RTPCR. Toxicol Sci. 2007; 95: 356-368. 